\title{
The contributions of temperature and of the input of organic matter in controlling rates of sediment methanogenesis ${ }^{1}$
}

\section{Carol A. Kelly ${ }^{2}$ and David P. Chynoweth ${ }^{3}$}

Department of Environmental and Industrial Health, School of Public Health, University of Michigan, Ann Arbor 48109

\begin{abstract}
The roles of temperature and organic input in determining the rate of methane flux from anoxic sediments were examined under various laboratory and field conditions in two small Michigan lakes. As in other studies, rapid temperature increases in incubating sediment caused immediate increases in methane production rates (avg $Q_{10}=2.4$ ). Under in situ conditions, where the hypolimnetic temperature is relatively cold and unchanging for long periods, methane flux was linearly related $(P \leqslant 0.01)$ to organic input in these two and three other lakes for which data were available. In addition, the proportion of organic input released as methane $(47 \pm 9 \%)$ was close to the theoretical maximum $(40 \pm 8 \%)$ and was not related to temperature. When temperature is constant for long periods, as during summer stratification, $\mathrm{CH}_{4}$ production adjusts maximally to organic input. When temperature changes rapidly, its effect will be predictably superimposed upon that of organic input.
\end{abstract}

The effect of temperature and of the supply of organic matter on rates of methanogenesis in freshwater sediment have becn studied separately. Zeikus and Winfrey (1976) proposed that temperature greatly limits the activity of methanogenic bacteria in Lake Mendota sediments. Methane production in sediments incubated in the laboratory increased at higher temperatures with optima at $35^{\circ}$ $42^{\circ} \mathrm{C}$, much higher than the natural lake temperatures, and a seasonal increase in numbers of methanogens was correlated with warming water temperatures. Baker-Blocker et al. (1977) found a direct relationship between methane bubble releases and air temperature in three wetland systems and developed a mathematical relationship that was used to predict methane flux rates in large wetland areas around the world from available temperature data. Methane release in sediments was also linearly related to the rate of organic carbon input in four lakes (Robertson 1979).

\footnotetext{
1 This work was supported by NIEHS training grant 5TOIES 00138 and by a Rackham dissertation grant to Carol Kelly.

${ }^{2}$ Current address: Freshwater Institute, 501 University Crescent, Winnipeg, Manitoba R3T 2N6.

${ }^{3}$ Current address: Institute of Gas Technology, 3424 S. State St., Chicago, Illinais 60616.
}

By a detailed study of two lakes with different organic inputs and sediment temperatures, we hoped to clarify the role of cach in influcncing methanogenic rate. We also compiled measurements of in situ temperature, organic input, and methane release in three other lakes for comparison.

We thank R. Cook, R. J. Flett, R. D. Hamilton, and J. W. M. Rudd for reviewing the manuscript. M. Klug, R. Fallon, and D. Schindler shared unpublished data. We also thank B. Manny for performing many of the organic carbon analyses.

\section{Methods}

Study sites-Frain's Lake and Third Sister Lake are small hard-water kettle lakes near Ann Arbor, Michigan $\left(42^{\circ} 17^{\prime} \mathrm{N}\right.$, $83^{\circ} 40^{\prime} \mathrm{W}$ ). Frain's Lake has a maximum depth of $9 \mathrm{~m}$, is 6.8 ha in area, and is surrounded by farmland. Third Sister Lake is $18 \mathrm{~m}$ deep, 4.1 ha in area, and has a mostly forested watershed. Frain's Lake is about twice as productive as Third Sister Lake; both develop completely anoxic hypolimnia in the summer (Robertson 1979).

Laboratory incubations of sedimentCores were taken with a 5-cm-diameter Wildco gravity corer in the central area of each lake while the lakes were strati- 
Table 1. Initial rates of methane production $\left(\mathrm{mmol} \cdot \mathrm{m}^{-2} \cdot \mathrm{d}^{-1}\right)$ measured in vitro in core sections at various temperatures.

\begin{tabular}{|c|c|c|c|c|c|c|c|}
\hline & \multirow{2}{*}{$\underset{\left({ }^{\circ} \mathrm{C}\right)}{\text { Temp }}$} & \multicolumn{6}{|c|}{ Section, $\mathrm{cm}$} \\
\hline & & $0-3$ & $3-6$ & $6-9$ & $9-12$ & $12-15$ & $15-18$ \\
\hline \multicolumn{8}{|c|}{ Third Sister Lake } \\
\hline 3 Jun $76^{*}$ & $\begin{array}{c}4.5 \\
9 \\
19 \\
29\end{array}$ & $\begin{array}{r}3.6 \\
3.9 \\
8.5 \\
19.1\end{array}$ & $\begin{array}{r}1.8 \\
2.5 \\
9.6(6.1) \dagger \\
15.7\end{array}$ & $\begin{array}{l}0.67 \\
2.1 \\
6.2(4.3) \dagger \\
9.8\end{array}$ & $\begin{array}{r}1.2 \\
3.5 \\
8.6 \\
14.9\end{array}$ & $\begin{array}{r}2.9 \\
3.5 \\
7.3 \\
14.5\end{array}$ & $\begin{array}{r}1.4 \\
2.7 \\
4.1 \\
10.7\end{array}$ \\
\hline \multicolumn{8}{|l|}{ Frain's Lake } \\
\hline 23 Apr $76 \ddagger$ & $\begin{array}{r}9 \\
19 \\
29\end{array}$ & $\begin{array}{r}6.7 \\
18.0 \\
46.5\end{array}$ & $\begin{array}{r}3.6 \\
12.7 \\
41.4\end{array}$ & $\begin{array}{r}2.8 \\
8.1 \\
24.5\end{array}$ & $\begin{array}{r}2.8 \\
6.3 \\
19.9\end{array}$ & $\begin{array}{r}3.9 \\
6.0 \\
19.0\end{array}$ & $\begin{array}{r}3.9 \\
5.7 \\
20.5\end{array}$ \\
\hline 5 Jul $76 \ddagger$ & $\begin{array}{r}9 \\
19 \\
29\end{array}$ & $\begin{array}{r}8.7 \\
18.6 \\
23.3\end{array}$ & $\begin{array}{r}4.1 \\
6.5 \\
13.9\end{array}$ & $\begin{array}{r}4.5 \\
11.1 \\
19.1\end{array}$ & $\begin{array}{r}4.8 \\
7.5 \\
14.8\end{array}$ & $\begin{array}{l}3.0 \\
2.5 \\
4.8\end{array}$ & $\begin{array}{r}3.9 \\
4.2 \\
10.8\end{array}$ \\
\hline
\end{tabular}

* Avg of three cores, avg $s / x=20 \%$ (range $4-53 \%$ ).

Number in parentheses is a second rate which established itself at that temperature before shift to next temperatures took place.

$\$$ Avg of two cores, avg $s / \bar{x}=22 \%$ (range $0-60 \%$ ).

fied and the bottom water was anoxic. Two from Frain's Lake were taken on 23 April 1976 and two on 5 July 1976; three from Third Sister Lake were taken on 3 June 1976. Cores were kept on ice for transport and until sectioning, within 3$4 \mathrm{~h}$ of retrieval.

Cores were sectioned at $3-\mathrm{cm}$ intervals under nitrogen and the sections incubated in a circulating water bath under an atmosphere of $90 \%$ argon and $10 \% \mathrm{CO}_{2}$ (chosen to preserve the bicarbonate equilibrium at its initial condition) in continuously shaken Warburg vessels (see Kelly and Chynoweth 1979). All sections were initially incubated at in situ temperatures $\left(4.5^{\circ} \mathrm{C}\right.$ for Third Sister Lake and $9^{\circ}$ for Frain's Lake) for about 3 days during which the initial rate of methane production was determined by periodic removal of gas samples for analysis.

After this, the temperature was increased to $9^{\circ} \mathrm{C}$ (for Third Sister Lake), then to $19^{\circ}$ and $29^{\circ}$. Temperature increases took $30 \mathrm{~min}$ and incubation at each temperature was for 1-3 days-the minimum time necessary for a valid measurement of methane production rate.

The upper $3 \mathrm{~cm}$ of the cores incubated at in situ temperatures give rates of methane production similar to the hypolimnetic methane fluxes in the lakes during stratification (Kelly and Chynoweth
1980). Deeper sections seem to be stimulated above their natural rates by such handling, so that those rates are probably useful only as relative values.

In situ temperature, methane flux, and organic input-Temperature in the water and surface sediment was measured with a YSI oxygen-temperature probe, calibrated at $0^{\circ} \mathrm{C}$.

Water samples were collected with a van Dorn bottle and analyzed for methane (Rudd et al. 1974). Bubble evolution was measured with large (0.6-m diam) inverted funnels attached to water-displacement collection bottles from which gas samples could be removed through a serum stopper. Methane was measured with a Packard 800 series gas chromatograph equipped with thermal conductivity detector, a 1.8-m Porapak Q column, and with an argon carrier. Total methane flux during summer stratification was calculated by summing diffusive flux and bubble evolution (Kelly and Chynoweth 1979).

Samples to measure input to the sediments of particulate organic carbon were taken in cylindrical sediment traps, 7.3 $\mathrm{cm}$ in diameter and $17 \mathrm{~cm}$ high (Robertson 1979). Three sets of four cylinders each were placed at random sites $1 \mathrm{~m}$ above the hypolimnetic sediment. Measurements were made only during strat- 
Table 2. $Q_{10}$ values for rate of $\mathrm{CH}_{4}$ production in sediment incubated in vitro. Ratios are for adapted rates (not initial) when adaptation was observed. Numbers given are averages for all samples. $Q_{10}=$ ratio of rate of $\mathrm{CH}_{4}$ production at $(X+10)^{\circ} \mathrm{C}$ to the rate at $X^{\circ} \mathrm{C}$. $Q_{10}$ for this shift from $4.5^{\circ}-9^{\circ} \mathrm{C}$ was calculated by assuming that observed change would be directly proportional to a $10^{\circ} \mathrm{C}$ change.

\begin{tabular}{|c|c|c|c|c|c|c|c|c|}
\hline & \multirow{2}{*}{$\begin{array}{c}\text { Interval } \\
\left({ }^{\circ} \mathrm{C}\right)\end{array}$} & \multicolumn{6}{|c|}{ Section, cm } & \multirow[b]{2}{*}{ Avg } \\
\hline & & $0-3$ & $3-6$ & $6-9$ & $9-12$ & $12-15$ & $15-18$ & \\
\hline \multicolumn{9}{|c|}{ Third Sister Lake } \\
\hline 3 Jun 76 & $\begin{array}{c}4.5-9 \\
9-19 \\
19-29\end{array}$ & $\begin{array}{l}1.2 \\
2.2 \\
2.2\end{array}$ & $\begin{array}{l}1.9 \\
3.8 \\
2.6\end{array}$ & $\begin{array}{l}5.7 \\
3.0 \\
2.3\end{array}$ & $\begin{array}{l}5.3 \\
2.5 \\
1.7\end{array}$ & $\begin{array}{l}1.5 \\
2.1 \\
2.0\end{array}$ & $\begin{array}{l}3.1 \\
1.5 \\
2.6\end{array}$ & $\begin{array}{l}3.1 \\
2.5 \\
2.2\end{array}$ \\
\hline \multicolumn{9}{|l|}{ Frain's Lake } \\
\hline 23 Apr 76 & $\begin{array}{r}9-19 \\
19-29\end{array}$ & $\begin{array}{l}4.1 \\
1.3\end{array}$ & $\begin{array}{l}4.7 \\
2.9\end{array}$ & $\begin{array}{l}3.0 \\
2.4\end{array}$ & $\begin{array}{l}2.5 \\
2.3\end{array}$ & $\begin{array}{l}1.6 \\
3.4\end{array}$ & $\begin{array}{l}2.6 \\
1.8\end{array}$ & $\begin{array}{l}3.1 \\
2.4\end{array}$ \\
\hline 5 Jul 76 & $\begin{array}{r}9-19 \\
19-29\end{array}$ & $\begin{array}{l}2.1 \\
1.3\end{array}$ & $\begin{array}{l}1.6 \\
2.1\end{array}$ & $\begin{array}{l}2.5 \\
1.7\end{array}$ & $\begin{array}{l}1.6 \\
2.0\end{array}$ & $\begin{array}{l}0.83 \\
1.9\end{array}$ & $\begin{array}{l}1.1 \\
2.6\end{array}$ & $\begin{array}{l}1.6 \\
1.9\end{array}$ \\
\hline
\end{tabular}

ification (beginning in April or May) and were stopped when the thermocline came within $1 \mathrm{~m}$ of the upper trap edges (usually early November). Sediment trap material was acidified to remove inorganic carbon. Total organic carbon was then measured by combustion to carbon dioxide using a Hewlett-Packard 185B CHN analyzer. In 1976, a simpler assay (volatile solids: Am. Public Health Assoc. 1971) was used on a large number of samples to determine trap collection variability (Robertson 1979).

\section{Results}

Laboratory incubations of sedimentWhen the incubation temperature of a core section was increased, the rate of methane production increased almost immediately in all surface sections and in most of the deeper sections. In a few of the deeper sections there was a lag of about $40 \mathrm{~h}$ after the shift from $19^{\circ}$ to $29^{\circ} \mathrm{C}$. In most cases the production rate remained linear until the next temperature shift, except where noted (Table 1). When the rate decreased just before a shift, this lower rate was used in computing the $Q_{10}$ for the next shift.

The magnitude of the increase in production rate was quite variable. The average $Q_{10}$ was $2.4 \pm 1.0$, with some particularly large values observed in the shift from $4.5^{\circ}$ to $9^{\circ} \mathrm{C}$ (Table 2 ).

We compared methane production rates for the two lakes by dividing the Frain's Lake rate by the Third Sister Lake rate at each incubation temperature (Table 3). In the upper sections, Frain's Lake rates averaged 1.8 times higher $(s)$ $\bar{x}=21 \%$ for all sections $0-9 \mathrm{~cm}$ : Table 3 ), while there was not much difference in the deeper sections $(\bar{x}=1.1$ times higher in Frain's Lake with $s / \bar{x}=28 \%$ for all sections 9-18 cm: Table 3).

In situ temperature, organic input, and methane flux-In both lakes, the anoxic sediment temperatures were similar from year to year. The sediment in the deepest part of Frain's Lake $(9 \mathrm{~m})$ warmed only from $7^{\circ}$ to $9^{\circ} \mathrm{C}$ during summer, while the shallower hypolimnetic sediment $(4 \mathrm{~m})$ reached $17^{\circ} \mathrm{C}$. In Third Sister Lake the deepest sediment $(18 \mathrm{~m})$

Table 3. Ratios of rates of methane production in Frain's Lake sediment to Third Sister Lake sediment when both are incubated at same temperature. Frain's Lake data for this table were averages of rates of methane production measured in cores taken on 23 April and 5 July 1976 (two cores each). Third Sister Lake measurements were average values for three cores taken on 3 June 1976. All cores were from central basin of each lake.

\begin{tabular}{rcccccc}
\hline $\begin{array}{c}\text { Incuba- } \\
\text { tion } \\
\text { temp } \\
\left({ }^{\circ} \mathrm{C}\right)\end{array}$ & $0-3$ & $3-6$ & $6-9$ & $9-12$ & $12-15$ & $15-18$ \\
\cline { 2 - 7 } & 0.0 & 1.5 & 1.7 & 1.1 & 0.99 & 1.4 \\
9 & 2.0 & 1.6 & 0.8 & 0.58 & 1.2 \\
19 & 2.2 & 1.0 & 1.6 & \multicolumn{6}{c}{ Section, cm } \\
29 & 1.8 & 1.8 & 2.2 & 1.2 & 0.82 & 1.5 \\
\hline
\end{tabular}


Table 4. In situ sedimentation rates, methane flux, and temperature during summer stratification in five lakes.

\begin{tabular}{|c|c|c|c|c|c|c|}
\hline \multirow{2}{*}{\multicolumn{2}{|c|}{ Lake* }} & $\begin{array}{l}\text { Sedimentation } \\
\text { rate }\end{array}$ & $\begin{array}{l}\text { Methane } \\
\text { flux rate }\end{array}$ & \multirow{2}{*}{$\begin{array}{c}\% \\
\text { Return }\end{array}$} & \multicolumn{2}{|c|}{ Hypolimnetic } \\
\hline & & \multicolumn{2}{|c|}{$\mathrm{mmol} \cdot \mathrm{m}^{-2} \cdot \mathrm{d}^{-1}$} & & $\begin{array}{c}\text { temp } \\
\left({ }^{\circ} \mathrm{C}\right)\end{array}$ & $\underset{(m)}{\operatorname{deppht}}$ \\
\hline Third Sister ${ }^{1}$ & $\begin{array}{l}1976 \\
1977\end{array}$ & $\begin{array}{c}15 \\
9.2\end{array}$ & $\begin{array}{l}5.4 \\
3.5\end{array}$ & $\begin{array}{l}36 \\
38\end{array}$ & $\begin{array}{l}4.5-7 \\
4.5-7\end{array}$ & $\begin{array}{l}10-16 \\
10-16\end{array}$ \\
\hline Frain's ${ }^{1}$ & $\begin{array}{l}1976 \\
1977\end{array}$ & $\begin{array}{l}33 \\
25\end{array}$ & $\begin{array}{l}19 \\
12\end{array}$ & $\begin{array}{l}58 \\
48\end{array}$ & $\begin{array}{l}7-17 \\
7-17\end{array}$ & $\begin{array}{l}4-10 \\
4-10\end{array}$ \\
\hline 227 (ELA, Ontario) & 1974 & $19^{2}$ & $10.8^{3}$ & 57 & $4-10$ & $4-10$ \\
\hline Mendota (Madison, Wis.) & 1977 & $67.5^{4}$ & $35.8^{4}$ & 53 & $9-16^{5}$ & $14-18$ \\
\hline $\begin{array}{l}\text { Wintergreen (Hickory } \\
\text { Corners, Mich.) }\end{array}$ & 1976 & $127^{6}$ & $49^{6}$ & 39 & $12-16^{7}$ & $3-6$ \\
\hline Avg for all lake-years & & & $47 \pm 9$ & & & \\
\hline
\end{tabular}

* Key to superscripts; 1-this study; 2-D. Schindler pers. comm.; 3-Rudd and Hamilton 1978; 4-Fallon et al. 1980; 5-Zeikus and Winfrey 1976, 6-M. Klug pors. comm.; 7-Strayer and Tiedje 1978.

$\dagger$ Depths in which methane accumulates.

remained at $4.5^{\circ}-5^{\circ} \mathrm{C}$, the shallow hypolimnetic sediment $(10 \mathrm{~m})$ warmed to $7^{\circ} \mathrm{C}$. The in situ flux of $\mathrm{CH}_{4}$ is thus derived from sediments at a range of temperatures. Since the sediment area is about the same at each meter depth interval, the various sediment depths contributed equally and the average temperature was the same as the median temperature in these two lakes.

The sedimentation rate in the more productive Frain's Lake was higher than in Third Sister Lake by a factor of 2.2 in 1976 and 2.7 in 1977 (Table 4). In situ methane flux was also higher in Frain's Lake than in Third Sister Lake by $3.5 \times$ in 1976 and $3.4 \times$ in 1977. The Third Sister Lake hypolimnion was colder (median temperature $6^{\circ} \mathrm{C}$ ) than Frain's Lake (median $12^{\circ}$ ). Both organic input and methane release decreased from 1976 to 1977, with no difference in hypolimnetic temperatures (Table 4).

It is hard to establish the true error of whole, lake estimates, including the errors introduced by bathymetric measurements. The variability from one sediment trap to another for a single period was low $(\max s / \bar{x}=12 \%$ ) when the total contents were used for volatile solids analy: sis. The variability for TOC analyses was higher $(\max s / \bar{x}=31 \%$ for any collection period), probably due to the smaller analytical sample size. The highest vari- ability in methane profiles (for completely separate samplings done on the same day) was $20 \%$ of the total lake methane value computed.

To gain a broader perspective on the relationships among in situ organic input, methane release, and temperature, we compiled data for five lakes where these measurements have been made (Table 4). In these lakes, methane release was linearly related to organic input $\left(r^{2}=\right.$ 0.95: Fig. 1). The relationship between methane release and temperature was exponential (Fig. 2), and the lakes showed a 10 -fold difference in release for $<10^{\circ} \mathrm{C}$ difference in temperature.

Because the proportion of the organic

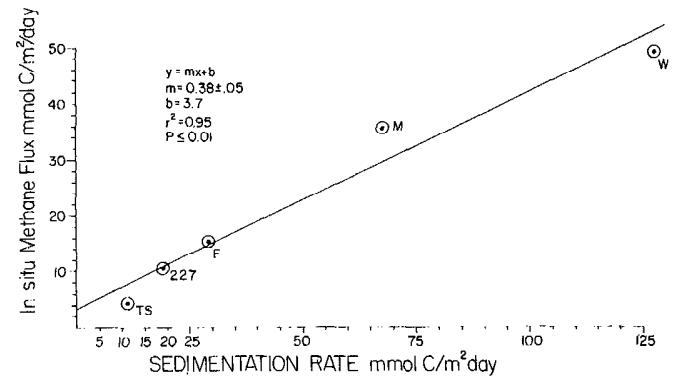

Fig. 1. In situ methane flux rate as a function of sedimentation rate of total organic carbon. Data from Table 4. TS-Third Sister Lake, 1976 and 1977 average; F-Frain's Lake, 1976 and 1977 average; 227-Lake 227; M-Lake Mendota; W-Wintergreen Lake. 


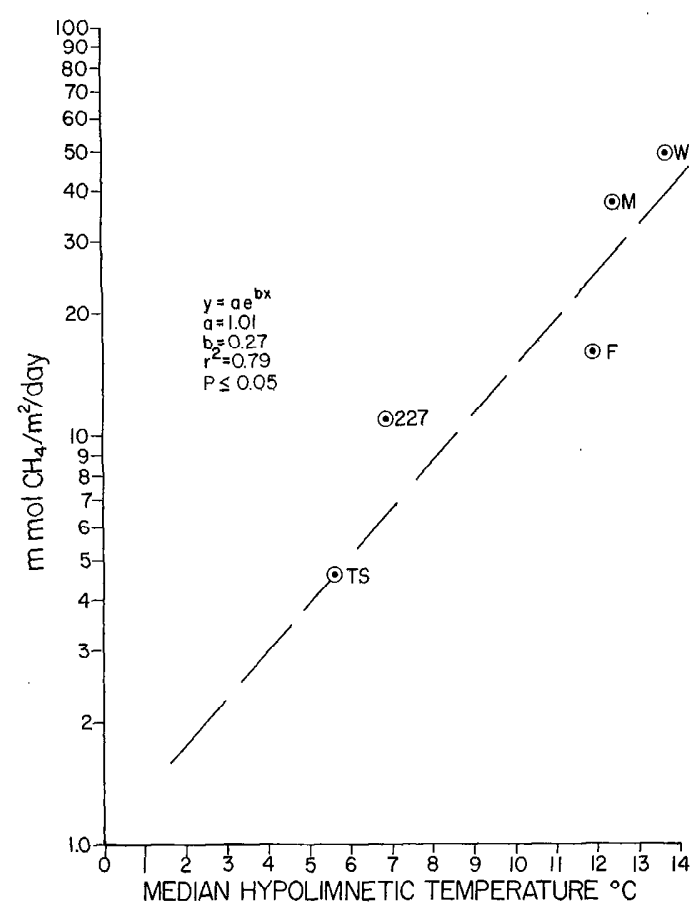

Fig. 2. In sitı methane flux rate as an exponential function of median hypolimnetic temperature. Data from Table 4; symbols as in Fig. 1. Median temperature was chosen because we did not have enough data for all the lakes for a more complete analysis of temperature vs. time and sediment area.

input that was returned as methane varied somewhat from lake to lake $(47 \pm 9 \%$ : Table 4), we examined this proportion to see if it was related to hypolimnetic temperature. We found no such relationship (Fig. 3).

\section{Discussion}

The general phenomenon of increased microbial activity resulting from a rapid increase in temperature has been shown for cultures (e.g. Schaecter et al. 1958; Hotle 1979), as well as specifically for sediment methanogenesis (Zeikus and Winfrey 1976). We also found immediate increases in methane production with increases in temperature, with the response somewhat higher than the expected doubling per $10^{\circ} \mathrm{C}$ and also quite variable (Table 2 ; avg $Q_{10}=2.4 \pm 1.1$ ).

The interesting feature of our incubation experiments was that the Frain's

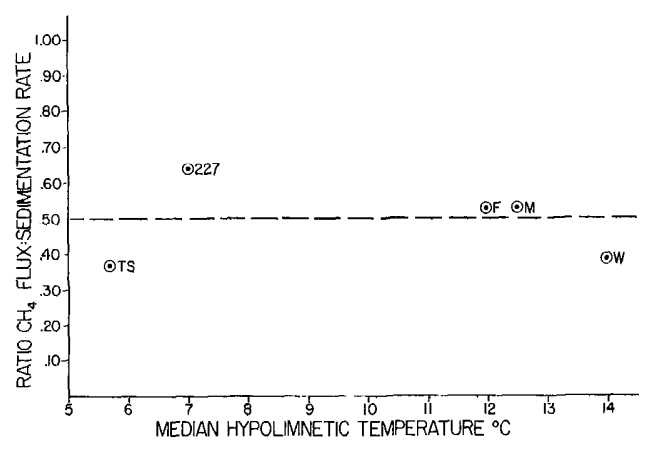

Fig. 3. Ratio of carbon flux as methane to incoming carbon flux as particulate organic matter as a function of median (Fig. 2 legend) hypolimnetic temperature. Data from Table 4; symbols as in Fig. 1.

Lake surface sections produced methane at about twice the rate of those from Third Sister Lake at identical temperatures (Table 3). Sediment from the colder lake bottom (Third Sister) did not "catch up" to sediment from the warmer lake as its temperature was increased. Also, the difference in the methane production rates of surface sediments $(2.0 \times, 0-3 \mathrm{~cm}$ : Table 3) at the same temperature was about the same as the difference in rate of organic input to the sediments (Frain's Lake was just over twice that of Third Sister Lake: Table 4). This indicates that the influence of organic input was quantitatively maintained as the temperature was increased.

In contrast to the surface sections, where new organic input would be most important, deeper sections from both lakes produced methane at similar rates when incubated at the same temperature (Table 3), suggesting that there is about the same amount of organic carbon available for decomposition at these depths. Activity in these samples is low and probably represents slow microbial breakdown of relatively refractile compounds.

Our compilation of in situ measurements of rates of organic sediment input and methane flux (Table 4) supports the hypothesis that, under conditions of long, undisturbed stratification and fairly constant temperature, the rate of methane flux is influenced primarily by the rate of 
organic input. The relationship between rates of organic input and methane flux is strongly linear $(P \leqslant 0.01$ : Fig. 1). If both temperature and organic input were important in determining rates of hypolimnetic methane flux, we would expect to see a higher proportion of methane returned from the carbon input into the warmer sediments. However, the proportion returned in the warmest hypolimnion (Wintergreen) was about the same as that in the coldest (Third Sister Lake), and there was no overall trend in the five lakes (Fig. 3). Temperature did not seem to play a significant role under these conditions.

In addition to the linearity of the relationship observed between organic input and methane flux rates, the value of the "\% return" ( $47 \pm 9 \%$ : Table 4$)$ is also important in considering the microbial activity level in cold hypolimnetic sediments. The maximum amount of methane that can be produced from a known input of organic matter can be estimated from typical ratios of the two possible anoxic end products, $\mathrm{CH}_{4}$ and $\mathrm{CO}_{2}$. In three ELA lakes where $\mathrm{CO}_{2}$ fluxes from sediment are supported essentially by biological activity alone (there is very little precipitated carbonate), the average anoxic ratio of $\mathrm{CO}_{2}: \mathrm{CH}_{4}$ production was $1.5 \pm$ 0.6 (C. Kelly unpubl.). Thus, for cvery mole of methane produced from sediments, there are also about 1.5 moles of $\mathrm{CO}_{2}$, and the highest $\mathrm{CH}_{4}$ return expected would be about $40 \pm 8 \%$ of the organic input. In order to apply this relationship to rates of input and return measured during stratification, one must assume that the current rate of methane fux is coupled primarily to the current rate of input and not to some previous input. This seems to be the case. When the sedimentation rate in both lakes decreased in 1977 (compared to 1976), methane flux rates fell by proportionate amounts (Table 4). Also, it is known from other studies (Schindler et al. 1973) that summer and fall are the most important periods for particulate losses from the water column. Winter and spring would not be cxpected to be times of heavy organic sedi- mentation which would then influence decomposition rates the following summer.

From the above evidence that stratification flux rates are coupled to input rates over the same period and from the ratio of anoxic $\mathrm{CH}_{4}$ to $\mathrm{CO}_{2}$ fluxes in lakes, the highest rate of organic input that could be returned as methane would be about $40 \pm 8 \%$, with the rest going to $\mathrm{CO}_{2}$. The observed average return rate of $47 \pm 9 \%$ (Fig. 1) is very close to this value. This means that during summer stagnation, when the temperature is relatively low and constant for 5-7 months, microbial activity is apparently maximally adjusted to the rate of incoming substrate. If this temperature regime were disturbed suddenly, as with heated industrial wastewater (Hofle 1979), methane production would be expected to increase as it did in our core incubations. The increase would be temporary, however, until the supply of organic carbon was exhausted.

In view of the strong linear dependence of methane flux on organic input (Fig. 1), what is the significance of the exponential relationship observed between methane flux and temperature? The change in rate of flux from one lake to another, for a $10^{\circ}$ change in temperature, was about $100 \times$ (Fig. 2) rather than $2-3 \times$ as in the incubations; such a large difference means that some factor other than the change in temperature was primarily responsible. A similar exponential curve could be produced for temperature vs. organic input, since organic input and methane flux are linearly related (Fig. 1). This probably results from the effect of basin morphometry on primary production, with shallower lakes being more productive (Sakamoto 1966; Fee 1979) and also tending to have warmer hypolimnia. Thus, the exponential relationship between temperature and $\mathrm{CH}_{4}$ flux (Fig. 2) should not be interpreted as direct cause and effect.

Baker-Blocker et al. (1977) also observed an exponential-type relationship between air temperatures and methane bubble fluxes in three ponds or wetlands. However, these were very shallow sedi- 
ment environments where rapid fluctuations in air temperature would be expected to result in similar fluctuations in sediment temperatures, and they measured changes in methane flux rates over short periods (3 days-2 weeks). Thus, their situation was more similar to our incubation experiments than to deeper hypolimnetic sediments. Not surprisingly, then, they observed an approximate 2$4 \times$ increase in methane flux with a $10^{\circ} \mathrm{C}$ increase in temperature. The three ponds in their study may have had similar organic inputs, and most of the rates measured were lower than those in the lakes cited here. More measurements on different wetlands would help to establish the usefulness of their recommendation of temperature as a predictor of methane flux in shallow systems. Another precaution for the use of the temperature-flux relationship they developed is that it gives a minimum methane flux at $10^{\circ} \mathrm{C}$. This may cause underestimates of fluxes from wetlands in colder areas, since this temperature is obviously not the lower limit for sediment methanogenesis.

In conclusion, the results presented here give a more comprehensive view of the roles of temperature and organic input in determining methanogenic activity than was previously available. As seen before, short term experiments showed that the natural, cold-temperature methanogenic rate in a particular sediment could be increased readily by increasing the temperature. However, when temperature was fairly constant for long periods, as during summer stratification, the rate of methane flux was directly proportional to (Fig. 1) and maximally adjusted to the rate of carbon input $\left(\mathrm{CH}_{4} \mathrm{flux}\right.$ averaged $47 \%$ of organic input: Table 4 ). Zeikus and Winfrey (1976) did in fact suggest that although sediment methanogens seemed to be severely temperature limited, this did not mean that they were not optimally adapted to their environment in some other way. Our study has demonstrated that in situ methanogenic activity was maximally adapted to organic input in the absence of rapid temperature changes.

\section{References}

American Public IIEalth Association. 1971. Standard methods for the examination of water and wastewater, 13th ed.

Baker-Blocker, A., T. M. Donahue, and K. H. MANCY. 1977. Methane flux from wetland areas. Tellus 29: 245-250.

FALlON, R. C., S. IIARRITS, R. S. HANSON, AND T. D. BROCK. 1980. The role of methane in internal carbon cycling in Lake Mendota during summer stratification. Limnol. Occanogr. 25: 357-360.

FEE, E. 1979. A relation between lake morphometry and primary productivity and its use in interpreting whole-lake eutrophication experiments. Limnol. Oceanogr. 24: 401-416.

Hofi.E, M. G. 1979. Effects of sudden temperature shifts on pure cultures of four strains of freshwater bacteria. Microb. Ecol. 5: 17-26.

Kelly, C. A., AND D. P. Cinynoweti. 1979. Methanogenesis: A measure of chemoorganotrophic (heterotrophic) activity in anaerobic lake sediments, p. 164-179. In J. S. Costerton and R. R. Colwell [eds.], Native aquatic bacteria: Enu moration, activity and ecology. ASTM STP 695.

- ANI - 1980. Comparison of in situ and in vitro rates of methane release in freshwater sediments. Appl. Environ. Microbiol. 40: 287-293.

Robertson [KelLy], C. 1979. Quantitative comparison of the significance of methane in the carbon cycles of two small lakes. Arch. Hydrobiol. Bcih. Ergeb. Limnol. 12: 123-135.

Rudd, J. W., and R. D. Hamituton. 1978. Methane cycling in a eutrophic shield lake and its effects on whole lake metabolism. Limnol. Oceanogr. 23: 337-348.

,-- , AND N. E. CAMPBell. 1974. Measurement of microbial oxidation of methane in lake water. Limnol. Oceanogr. 19: 519-524.

Sakamoto, M. 1966. Primary production by phytoplankton community in some Japanesc lakes and its dependence on lake depth. Arch. IIydrobiol. 62: 1-28.

Schaecter, M., O. MaAloe, and N. O. KJeldGAARD. 1958. Cell size and composition in different inedia. J. Gen. Microbiol. 19: 592-605.

SCHINDI.ER, D. W., AND OTHERs. 1973. Eutrophication of Lake 227 by addition of phosphate and nitrate: The second, third, and fourth years of enrichment, 1970, 1971, and 1972. J. Fish. Res. Bd. Cin. 30: 1415-1440.

StrayeR, R., ANI J. TIEDJE. 1978. In situ methane production in a small hypereutrophic hardwater lake: Loss of methane from sediments by vertical diffusion and ebullition. Limnol. Occanogr. 23: 1201-1206.

ZeIKUS, J. G., ANI M. R. Winfrey. 1976. Temperature limitation of methanogenesis in aquatic sediments. Appl. Environ. Microbiol. 31: 99-107.

Submitted: 2 November 1979 Accepted: 12 March 1981 